\title{
ナノマテリアルそのリスク管理に関する各国機関の動向と規制の現状について
}

\author{
庄 野文章, * 熊本 正 俊, 井上耕三
}

\section{Trends of Activities in International Organization and Authorities in Each Country Regarding Risk Management of Nanomaterials}

\author{
Fumiaki Shono, ${ }^{*}$ Masatoshi Kumamoto, and Kozo Inoue \\ Japan Chemical Industry Association; Sumitomo Rokko Bldg., \\ 1-4-1 Shinkawa, Chuo-ku, Tokyo 104-0033, Japan.
}

(Received August 20, 2012)

\begin{abstract}
The Organisation for Economic Co-operation and Development (OECD) estimates that in 2015 the worldwide nanotechnology-related market will reach about US $\$ 1$ trillion and will create about two million additional jobs. The field began with the general technical industry, including many areas of the pharmaceutical, medical, agricultural, and environmental/energy industries, and recently has expanded to the formulation of nanotechnology. In particular, elements of nanometer-sized research and development $(R \& D)$ in the areas of drug delivery systems and nanomedicine are attracting widespread interest. On the other hand, the potential negative effects on human health and the environment of nanomaterials manufactured on the industrial scale have not been investigated in detail. Therefore, although the risks have not been fully clarified, research institutions and international organizations such as the OECD are working in earnest to elucidate them. This paper outlines the status of initiatives in industry and regulatory conditions and trends in individual countries and institutions to determine the safety of nanomaterials from the perspective of international relations.
\end{abstract}

Key words_ nanomaterial; risk management; health; environment; regulation; definition

\section{1. 緒言}

ナノテクノロジー関連市場の世界規模は，OECD の試算では 2015 年には約 80 兆円に達すると予想さ れており，さらに約 200 万人の産業雇用を創出する ものと期待されている．分野としては，一般産業技 術分野を始めとし，医薬，医療，農業，環境・エネ ルギー等の多くの分野が挙げられ，最近は特にナノ テクノロジーを製剤技術に応用し，ナノメートルサ イズの構成要素を有する「ナノ医薬品」あるいは 「ナノメディシン」の分野や drug delivery systems （DDS）の応用分野での研究開発が活発である。ナ ノマテリアルはこのように多様な分野にわたり世界 的規模でその素材と応用開発を中心とした精力的な 研究, 商品開発活動が進められている. 一方で, 現

The authors declare no conflict of interest.

一般社団法人日本化学工業協会（干104-0033 東京都中 央区新川 1-4-1 住友六甲ビル 7 階)

*e-mail: fshono@ jcia-net.or.jp

本総説は, 日本薬学会第 132 年会シンポジウム S 25 で

発表したものを中心に記述したものである.
在まで工業的に製造されるナノマテリアルが人の健 康や環境に悪影響を及ぼしている明確な事実は報告 されていない。しかしながらそのリスクについては まだ十分に明らかにされておらず，各国の研究機関 や OECD 等の国際機関がその解明に本格的に取り 組んでいるところである.ナノマテリアルの実用化 をさらに進めるうえで，ヒトの健康や環境に及ぼす リスクに関して, 解決すべき課題としては, 実態調 査, 測定法の開発, 有害性評価法の確立, 曝露評価 法の確立など多岐にわたる。現在，わが国において は独立行政法人新エネルギー・産業技術総合開発機 構 (New Energy and Industrial Technology Development Organization; NEDO）の委託事業として, 独 立行政法人産業技術総合研究所を核とする共同プロ ジェクトが精力的に進められている。化学業界では 社日本化学工業協会 (日化協) の化学品管理委員会 新規課題対応 WG が中心となって，国内外の機関 との対応や参画, 規制当局との対応を行つている. また 2003 年 10 月ナノテクノロジーとビジネスマッ 
チングによる新しい産業を発掘することを目的とし て，国内ナノテクノロジー関係の電機・電子・化学 メーカーを中心に発足したナノテクノロジービジネ 又推進協議会 (Nanotechnology Business Creation Initiative; NBCI）でも様々な活動を実施している. 本稿では国際的なナノマテリアル関係の安全性に関 する各国各機関の動向及び規制の状況や産業界の取 組状況を中心に概説する.

\section{2. 国際機関の動向 OECD (経済協力開発機構)} 等

OECD がナノマテリアル（ナノ粒子）に関する 安全性の議論を開始したのは第 37 回 Joint Meeting に遡る。以降，2006 年 2 月 OECD 理事会にて工業 用ナノ材料の安全性問題に関する作業部会設置につ いて正式承認され 2006 年 10 月からヒト健康及び環 境安全に係わる作業部会（Working Party on Manufactured Nanomaterials; WPMN）がその活動を開 始した。 その後第 3 回の作業部会で新たに 2 つのプ ロジェクト, 第 7 回の作業部会で 1 つのプロジェク トが追加され現在，計 9 プロジェクトが活動してい る (Fig. 1).

日本では独立行政法人新エネルギー・産業技術総 合開発機構（NEDO）の委託事業として，Project 3 を中心に独立行政法人産業技術総合研究所を核と する共同プロジェクトが精力的に進められているほ か, 独立行政法人物質・材料研究機構, 環境省, 厚 生労働省などが積極的に研究に取り組んでいる．ま た日化協は, Business and Industry Advisory Committee（BIAC）ナノテクノロジー委員会日本代表 委員として, OECD 工業ナノ材料安全作業部会 （WPMN スポンサーシッププログラム）PJ3，PJ8 に参加しており，PJ3 では会員会社にサンプル提供 及び製造データの開示要請，PJ8 では労働現場にお ける曝露測定に協力している（Table 1).

そのほか国際的には，国連環境計画（United Nations Environment Programme; UNEP) SAICM ICCM-2（2009 年 5 月） でナノマテリアルが Emergency Issue としてとりあげられ，各国際機関及び 産業界（ICCA 等）でこれに呼応した取り組みが進 められている. 国際標準化機構 (International Organization for Standardization; ISO) ではナノテク ノロジー分野での国際標準化活動を進めるための技 術委員会が設置され，ナノテクノロジーの持続的か

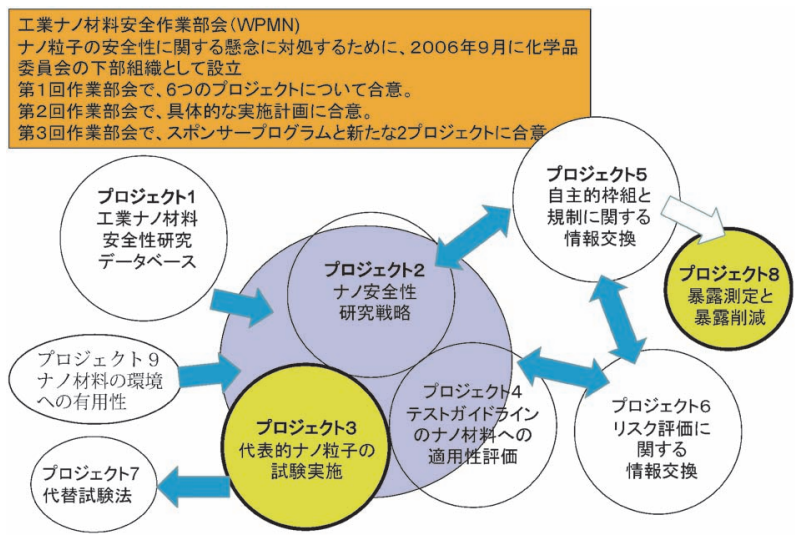

Fig. 1. OECD Working Paries for Nanomaterials

つ責任ある開発，円滑な国際流通，消費者あるいは 環境保護法等の改善を支援する活動が進められてい る。また製造・使用・廃棄における実践規範を促進 する基準を作成するため，用語と命名法，計測とキ ヤラクタリゼーション, 健康, 安全及び環境及び材 料規格の各 WG を設置し活動中である。 2010 年 10 月 ISO TC 229 事務局は，ナノ・ラベリング規格提 案(ISOTC 229/DTS13830) を配布した。本内容は, 予防原則に基づいて工業ナノ粒子（manufactured nanoparticles；MNP）及び含有製品の包装にラベル を要求するもので欧州標準化委員会 (Comité Européen de Normalisation; CEN) から各国間での議 論，検討が一切ない状況で採決の手続きが進められ た。化協からは，本件に関し，(1)関連の OECD 試験法の確立，用語，材料特性等について国際的な 合意形成の下での十分な科学的検討がなされること, (2)ISO 等での規格作成により認証方法が確立された うえで，国際的な整合性が確保された場合にのみラ ベリング対象とすべきと主張したところである.

以下各国，各機関の取り組みと規制状況について 概説する.

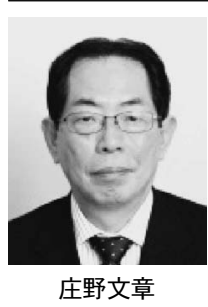

1975 年甲南大学理学部応用化学科卒, 同年，住友化学工業侏入社，生物科学 研究所配属. 標識化合物合成研究, 診 断薬開発，医薬代謝研究に従事。1991 年大阪大学薬学研究科, 医薬品の代謝 研究で学位取得. 以後, 東京本社にて 一般化学物質の化学品管理, 防疫薬, バイオサイド開発に従事。2006 年社日 本化学工業協会出向. 現 常務理事. 
Table 1. OECD WPMN Sponsorship Program

April, 2011

\begin{tabular}{|c|c|c|c|}
\hline & Lead sponsor $(s)$ & Co-sponsor (s) & Contributor \\
\hline Fullerenes（C60） フラーレン & Japan, US & & Denmark, China \\
\hline SWCNTs 単層カーボンナノチューブ & \multirow{2}{*}{ Japan, US } & \multirow{2}{*}{ Korea, BIAC (MW) } & \multirow{2}{*}{$\begin{array}{l}\text { Germany, EC, BIAC, Canada, } \\
\text { China, France }\end{array}$} \\
\hline MWCNTs 多層カーボンナノチューブ & & & \\
\hline Silver nanoparticles 銀ナノ粒子 & US, Korea & $\begin{array}{l}\text { Australia, Canada, Germany, } \\
\text { Nordic Council of Ministers }\end{array}$ & $\begin{array}{l}\text { France, Netherlands, EC, China, } \\
\text { BIAC }\end{array}$ \\
\hline Iron nanoparticles 鉄ナノ粒子 & China & BIAC & $\begin{array}{l}\text { Canada, US, Nordic Council of } \\
\text { Ministers }\end{array}$ \\
\hline Titanium dioxide (二) 酸化チタン & France, Germany & $\begin{array}{l}\text { Austria, Canada, Korea, Spain, } \\
\text { US, EC, BIAC }\end{array}$ & Denmark, Japan, UK, China \\
\hline $\begin{array}{ll}\text { Aluminium oxide } & \begin{array}{l}\text { 酸化アルミニウム } \\
\text { (別名 アルミナ) }\end{array}\end{array}$ & & & Germany, Japan, US \\
\hline Cerium oxide 酸化セリウム & $\mathrm{UK} / \mathrm{BIAC}, \mathrm{US}$ & Australia, Netherlands, Spain & $\begin{array}{l}\text { Denmark, Germany, Japan, Swit- } \\
\text { zerland, EC }\end{array}$ \\
\hline Zinc oxide 酸化亜鉛 & $\mathrm{UK} / \mathrm{BIAC}$ & Australia, US, BIAC & $\begin{array}{l}\text { Canada, Denmark, Germany, } \\
\text { Japan, Netherlands, Spain, EC }\end{array}$ \\
\hline Silicon dioxide 二酸化ケイ素 & France, EC & Belgium, Korea, BIAC & Denmark, Japan \\
\hline Dendrimersデンドリマー & & Spain, US & Austria, Korea \\
\hline Nanoclays 粘土ナノ粒子 & BIAC & & Denmark, US, EC \\
\hline Gold nanoparticles 金ナノ粒子 & South Africa & US & Korea, EC \\
\hline
\end{tabular}

\section{3. 米国}

米国でナノマテリアルについては, 労働安全衛生 局 (Occupational Safety and Health Administration; OSHA）の1970 年労働安全衛生法（Occupational Safety and Health Act; OSHAct), 環境保護庁 (U.S. Environmental Protection Agency; EPA) の有害物 質規制法（Toxic Substances Control Act; TSCA）, 連邦殺虫剂 - 殺菌剂 - 殺鼠剂法 (Federal Insecticides, Fungicides and Rodenticide Act; FIFRA）及び 食品医薬品局（U.S. Food and Drug Administration; FDA）の連邦食品・医薬品・化粧品法（Federal Food, Drug, and Cosmetic Act; FFDCA）が関連す る規制となり各所轄官庁で検討が進められている.

3-1. OSHA の OSHAct OSHAct は, 「米国 の労働者のために可能な限り安全で健康な労働条件 を保証する」ことを目的としている．同法は労働省 労働安全衛生局（OSHA）が管轄し，労働環境から 生じる負傷と疾病の防止に関する科学的調查を実施 し, 勧告を行う国立労働安全衛生研究所 (National Institute for Occupational Safety and Health; NIOSH) も米保健社会福祉省内に設置されている.ナノマテ リアルに関し, OSHA が設定した許容曝露限界值 (permissible exposure limit; PEL) は現在, カーボ ンブラックに関する $3.5 \mathrm{mg} / \mathrm{m}^{3}$ という PEL（連邦 規則集第 29 巻第 1910 条 1000 項表 Z-1）のみであ る. 各雇用者は, 科学的な労働衛生基準を遵守する 必要があることに加え, 実行可能なリスク管理手法 が特定されている状況を前提として検討する必要が ある. OSHA は，ナノテクノロジーに関する研究 開発活動についても基準を定めており，(1) 研究施 設における有害化学物質に対する職業性曝露基準,

（2）危険有害性周知基準，（3）呼吸保護基準，(4)個 人用防護具基準, (5) 職業上の負傷・疾病に関する 記録・報告基準及び (6) 特定の物質別基準などが含 まれる.

NIOSH は, 2004 年, 職場におけるナノテクノロ ジーの潜在的重要性を研究するプログラムを開始 し，ナノマテリアルの有害性及び職場における曝露 に加え, ナノ粒子の曝露から保護する呼吸装置の有 効性に関する研究内容を公表している. ナノテクノ ロジーに現在従事している労働者を保護するリスク 管理戦略を策定する知識を活用するとともに,

NIOSH が今後, ナノテクノロジープログラム基準 に関する提案をOSHA に示す上で基礎となる研究 
調査も実施している。エネルギー省（U.S. Department of Energy；DOE）は 2007 年に, 指針書「ナノ マテリアルの環境安全衛生（ES\&H）に対するアプ ローチ」を公表している（DOE 2007 年）. ${ }^{1)}$ 同指針 書は, DOEの各研究施設内で「危険が確定されて いないナノマテリアルに付随する不確実性を統制 し，労働者が被る負傷，健康障害及び環境に対する 悪影響を許容レベル内に抑える場合の合理的な指 針」を示した 2009 年 1 月 5 日付の通達に関するべー スとなっている（DOE 2009 年). ${ }^{2}$ 本通達は，工業 ナノ粒子に関する安全な取扱いを提示するとともに, DOE 認可労㗢者安全衛生プログラムに関する文書 の一部として，すべてのナノマテリアル取扱労働者 に関する作業者名簿と従事記録の作成を義務付けた ものとなっている.

\section{3-2. EPA TSCA 及び FIFRA 関係ＥPA は} 2008 年 11 月, TSCA で重要新規利用規則（significant new use rule; SNUR) をシロキサン変性二 酸化ケイ素とアルミナナノ粒子に適用するとしてい

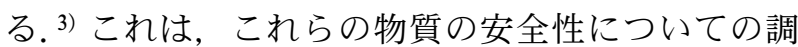
査を実施し，この結果に基づきその使用方法，取扱 いについて一定の条件を定めるものである．EPA はさらに重要な見解として 2008 年，TSCA に基づ き，EPA が新規化学物質とみなす物質を次のよう に明確化した。本来，TSCA は対象を化学物質とし ており有機合成物質等全く新規に創生されたものに ついて新規化学物質として取扱い，その申請 (premanufacture notification; PMN) を義務付けて いる. ナノマテリアルは本来, 既存の化学物質であ りこの対象に該当しなかったが，今回これを大幅に 変更する見解を示したものである，すなわち「ナノ スケールの物質は，分子的同一性が同じナノスケー ルではない対応物（ナノチューブや炭素フラーレン など）を有していない，若しくはなんらかの物質が ナノスケールとナノスケールでない形の両方で見い 出されるものの, 当該物質が事前に EPA に報告さ れておらず，いずれの形によっても TSCA 申請書 に記載されていない場合，当該物質は新規化学物質 とみなされる」4)である。事実，EPA は，2008 年 官報で，「カーボンナノチューブ (carbon nanotube; CNT）に関し，EPA では TSCA インベントリーに 記載された黒鉛又は他の炭素同素体とは異なる化学 物質とみなしている」との判断を強調した. ${ }^{5)}$ 今後,
この考え方が拡大する可能性が懸念される，2011 年 4 月時点で， 2005 年以降のカーボンナノチュー ブを含むナノスケールの新規化学物質届出が既に 100 件以上受理されており，新規物質か否かが不明 確な場合は EPA へ問い合わせることが推奨されて いる. 6

EPA は 2009 年, TSCA の第 5 (a) 条 (2) 項に基づ き，2つのカーボンナノチューブ化学構造によって 示される潜在的危険に直面する状況を抑制する，若 しくは他の方法で軽減する保護措置を義務付ける規 則作成を開始することを発表した. ${ }^{7)}$ また，2009 年 11 月 6 日, TSCA の第 5 (a) 条 (2) 項に基づき, PMN の対象となる 2 種類の化学物質に関する SNUR を 提案した. ${ }^{8)} \mathrm{EPA}$ は, 当該化学物質を多層カーボン ナノチューブと単層カーボンナノチューブとして一 般的に特定した。当該製造前届出によると，当該化 学物質は，TSCA の第 $5(\mathrm{e})$ 条に基づき，EPA が出 した同意命令に従っている，当該同意命令は，届出 者に対して，不当な潜在的危険に直面する状況を抑 制する，若しくは他の方法で軽減する保護措置を要 求している，さらに他の業者に対しては，生産，輸 入又は加工を開始する 90 日前までに SNUR に基づ き届出を行うことを要求している，その後， EPA は 2010 年 9 月 17 日に多層及び単層のカーボンナノ チューブに対する SNUR 最終規則を公布した. ${ }^{9)} さ$ らに EPA は 2012 年 4 月 4 日に 17 種の PMN 申請 された新規化学物質に対して SNUR 最終規則を公 布し，その中に含浸カーボンナノ構造体（infused carbon nanostructures）が含まれている. ${ }^{10)}$

EPA の FIFRA による農薬作業者の保護基準は, 農薬安全教育, 農薬散布通知, 個人用防護具の使 用，農薬散布後の立入制限間隔，污染除去用品，緊 急医療支援に関する要件が含まれている。EPA は，ナノテクノロジーに基づく製品に対する賠償請 求を監視しており 2007 年 9 月 21 日付で, 細菌を死 滅させる銀ナノ粒子を使用した製品を販売する会社 は，当該粒子が不当な環境・有害性を示さない旨の 科学的証拠を提出する必要があるとしている. ${ }^{11)}$ 2008 年 3 月 7 日, EPA は米国の農薬製造業者に対 し，パーソナルコンピューターのマウスとキーボー ドに「ナノシールド」コーティングを施したケース で「未登録の農薬を販売し，根拠のない有効性を主 張した」ことを理由に，20万 8000 ドルの罰金を科 
している. つい最近，これを受け「ナノシルバーや 他のナノメタルを使用した農薬製品に伴う危険と曝 露に関する評価に関連した一連の科学的問題の検討 と見直し」を目的として FIFRA 科学諮問委員会 （SAP）の会合が開催され, ${ }^{12)}$ ナノマテリアルを使 用した農薬に対する職業性曝露を対象に行われた.

EPA は FIFRA に基づいて，どんなナノスケール 物質が殺虫剤に含まれているかを情報収集する政策 提案を 2011 年 6 月 17 日に官報で公布した。 ${ }^{13)} \mathrm{EPA}$ は，FIFRA でナノスケールではない成分が既に登 録されていても，ナノスケール成分が新規の活性あ るいは不活性成分かをケースバイケースで判断する ことを提案している，EPA はナノスケール物質 (nanoscale material) の正式な定義をいまだ定めて ないが，本官報での広義の定義として，(1)粒子サイ ズの少なくとも一次元方向が約 1-100 nm, (2)同一 素材のより大きい粒子と比べて固有の（unique）あ るいは今までにない（novel）特性を示す, (3)天然 から生じるというよりは製造あるいは操作されたも の, としている.

3-3. FDA FFDCA FDA は 2012 年 4 月 20 日に，ナノテクノロジーを使用した食品関係及び化 粧品に関する安全性評価のためのガイダンス案を発 表した。 ${ }^{14)}$ 食品関係は，新興技術を含む重要な製造 工程変更が着色料を含む食品成分及び食品接触物質 の安全性と規制状況に与える影響の評価に関するも のであり，化粧品関係は化粧品製品中のナノマテリ アルの安全性に関するものである.いずれも最終化 されても法的拘束力を持つものではなく, ガイダン スという位置づけではあるが，企業側には安全性立 証の責任が求められる方向にある。これまでの経緯 として，2006 年米国消費者団体（国際技術評価セ ンター : International Center for Technology Assessment；ICTA）のナノマテリアルに関する規制の請 願に対し，FDA は産業界向けガイドラインを作成 し，食品や化粧品企業に対してデータの収集を継続 するように求め，同時に FDA は消費者団体の 2006 年の請願を却下した。米国消費者団体はこの内容を 不服としている.

\section{4. 欧州}

4-1. 欧州委員会 欧州委員会は 2005 年に報 告書「ナノサイエンスとナノテクノロジー：欧州の ためのアクション・プラン (2005-2009)」を発表し,
ナノサイエンスとナノテクノロジーに関する安全か つ統合され責任ある取り組みを早急に実施するため の, 相互に連結した数々の施策をうち出した. ${ }^{15)}$ 欧 州委員会, EU-OSHA リスク監視活動部門及び英国 王立国際問題研究所等によるナノテクノロジー，ナ ノマテリアルに関する報告書が多数公表されてい る. 欧州委員会通達「ナノマテリアルに関する規制 的側面」(欧州委員会 2008 年) ${ }^{16)}$ によると, 「労働 安全衛生の改善を促進するための施策の導入に関す る理事会指令 89/391/EEC」（いわゆる「枠組夕指 令」）は，ナノマテリアルを含む，あらゆる物質に 適用されるとともに, 従事する労働者の数, 生産さ れる材料の量又は用いられる技術の種類にかかわら ず，ナノマテリアルの生産と生産工程の全段階にお ける利用を含む，作業活動に適用されるとしてい る.ナノマテリアルのような新規技術の計画と導入 を実行する場合，枠組み指令 89/391/EEC の第 11 条と第 12 条に従って, 労働者又はその代表者と労 働条件・労働環境に関する協議を行う必要がある.

欧州委員会は,「新たに起こりつつある新規に特 定された健康リスクに関する科学委員会（Scientific Committee on Emerging and Newly Identified Health Risks; SCENIHR)」に対して，規制目的の「ナノ マテリアル」の定義を策定するにあたり考慮すべき 要素の科学的情報を提供するように命じた。これを 受け SCENIHR は，2010 年 6 月の意見書案「ナノ マテリアルの定義のための科学的根拠」に対する意 見募集を経て，2010 年 12 月に意見書最終版 ${ }^{17)} ま$ とめた。最終的に欧州委員会は 2011 年 10 月 20 日 の官報で「ナノマテリアルの定義に関する欧州委員 会勧告」18) を公布し，この勧告の中でナノマテリア ルは以下のように定義（以下要約のみ）された.

『「ナノマテリアル」とは, 非結合状態, あるいは 強い凝集体（aggregate）又は弱い凝集体（agglomerate）であり, 個数濃度のサイズ分布で 50 \%以上の粒子について 1 つ以上の外径が $1 \mathrm{~nm}$ か ら $100 \mathrm{~nm}$ のサイズ範囲である粒子を含む，自然 の, 又は偶然にできた, 又は製造された物質 （material）を意味する. 特定のケースであって, 環境・健康・安全, 若しくは競争力に対する懸念 に基づいて正当化される場合には，個数濃度のサ イズ分布の閾值である $50 \%$ は， 1\%-50\%の間の 閾值に置き換えてもよい』 
日本化学工業協会としては国際化学工業協会協議 会 (International Council of Chemical Associations; ICCA）のメンバーとして，欧州委員会の定義検討 の段階から，その定義は，各国の規制施行上重要な 影響を与えるとして当局に対し ICCA を通じ技術 的知見を基に意見具申を行った。 その結果当初案に ついてかなりの改善をみたが，依然この定義には課 題を有しており，当局は技術的な限界も認め，勧告 (Recommendation) としている. 前述の定義のナ ノサイズの範囲が(1) $1 \mathrm{~nm}$ から $100 \mathrm{~nm}$ であること, (2)サイズ分布閾值 1\%の妥当性，(3)“internal”の扱 いや天然物（natural）及び非意図的混入物（incidental）については更なる議論が必要である。も ともとナノマテリアルの測定手法が確立されていな い現在，ナノマテリアルを重量でなく粒子数あるい はその分布で定義することの基本的な問題を有して いる.この粒子数や分布をべースとした指標は安全 性評価上の指標としても問題があると考えており,

引き続き注視していく，以下，参考までに定義に関 する原文を示す。

- A natural, incidental or manufactured material containing particles, in an unbound state or as an aggregate or as an agglomerate and where, for 50 $\%$ or more of the particles in the number size distribution (NSD), one or more external dimensions is in the size range $1 \mathrm{~nm}-100 \mathrm{~nm}$.

- In specific cases and where warranted by concerns for the environment, health, safety or competitiveness the number size distribution threshold of $50 \%$ may be replaced by a threshold between 1 and $50 \%$.

- The definition will be used primarily to identify materials.
- Nanomaterials are not intrinsically hazardous per se but there may be a need to take into account specific considerations in their risk assessment.

欧州議会が 2012 年 4 月に採択した決議19)におい て内分泌攪乱物質, 混合化学物質による複合影響及 びナノマテリアルのリスクに対処するための特別措 置を 11 月に発表予定の EU の第 7 次環境行動計画 (7th Environmental Action Program; 7EAP) に盛り 込むことが求められている，参考までに国際機関， 各国政府の現状のナノマテリアルに関する定義一覧 を示す (Table 2).

\section{4-2. 欧州化学品庁 (European Chemicals Agen-} cy; ECHA)

4-2-1. REACH 欧州委員会通達「ナノマテ リアルに関する規制的側面」（欧州委員会 2008 年) ${ }^{16)}$ に記載されている内容によると，生産された ナノマテリアルはすべて，Registration, Evaluation, Authorisation, and Restriction of Chemicals (REACH) に規定される要件を満たす必要がある（EC No 1907/2006) 。 ${ }^{20)} \mathrm{REACH}$ にはナノマテリアルに明確 に言及している規定は存在しないものの，「化学物 質」の定義の中にナノマテリアルに関係する言及が みられる。欧州委員会環境総局（EU DG Environment）は,「REACH 登録一式文書中のナノマテリ アルの評価と入手情報の妥当性についての科学的技 術的サポート」に関するプロジェクト21)を 2010 年 3 月に立ち上げた。 このプロジェクトは，欧州委員 会の共同研究センター(Joint Research Centre; JRC) が REACH の所轄官庁である欧州化学品庁 (ECHA) と密接に連携して進めているもので，2つのタスク がある，タスク I の目的は，REACH の登録一式文 書の中でナノマテリアルも対象範囲に含まれている

Table 2. Comparison of Definitions for Nanomaterials

\begin{tabular}{l|l|l|l|l|l}
\hline \hline & \multicolumn{1}{|c|}{ ISO } & OECD 案 & ICCA 案 & EU 修正案 & Australia \\
\hline Size & $1-100 \mathrm{~nm}$ & $1-100 \mathrm{~nm}$ & $1-100 \mathrm{~nm}$ & $1-100 \mathrm{~nm}$ & $<100 \mathrm{~nm}$ \\
\hline Cut Off & 未定義1) & 未定義 & $>10 \%($ 重量) & $>50 \%(\mathrm{NSD})^{2)}$ & $>10 \%(\mathrm{NOP}) 3)$ \\
\hline 比表面積 & 未定義 & 未定義 & $>60 \mathrm{~m}^{2} / \mathrm{cm}^{3}$ & $\left.>60 \mathrm{~m}^{2} / \mathrm{cm}^{34}\right)$ & 未定義 \\
\hline 凝集体 & 未定義 & 未定義 & $\begin{array}{l}\text { アグリゲート, メグロ } \\
\text { メレト }>50 \%\end{array}$ & $\begin{array}{l}\text { アグリゲート } \\
\text { アグロメレト }\end{array}$ & 未定義 \\
\hline End-Prod. & 定義なし5) & 定義なし & 未定義 & 定義なし & 未定義 \\
\hline
\end{tabular}

\footnotetext{
1) 検討中であるが未決定. ${ }^{2}$ NSD: Particle in the number size distribution. ${ }^{3)}$ NOP: Number of particle. ${ }^{4)}$ Case by case. ${ }^{5}$ 定義は対象外.
} 
部分を特定し，その情報を科学的に評価したうえ で, 複数の要因が絡んでいる可能性のある不備にど う対処したらいいかを提案する。このタスク I が 2012 年 3 月に終了したことを受けて, 最終報告 書22)が公開された。本報告書は, 物質の同定, 物理 化学的性状，製造と使用，ヒト及び環境への影響, 分類と表示，曝露評価，リスク判定等に関して登録 一式文書中に提供されている情報が，ナノマテリア ル特有の性状や特性に鑑みると不十分あるいは不適 切な例が多いとして, 盛り込むべき情報を複数提言 している. 2012 年 2 月に開始されたタスク II の目 的は, タスク I で出された提案が経済と環境に及ぼ すかもしれない影響を評価することであり，最終報 告書は 2013 年 10 月に完成する予定である.

ECHA はナノマテリアルに関する REACH 実施 プロジェクト (REACH Implementation Project on Nanomaterials; RIP-oN） の報告書に基き，ナノマ テリアルの場合のその特性を考慮して，2012 年 4 月 30 日「情報要求と化学物質安全性評価（Information Requirements and Chemical Safety Assessment；IR\&CSA）に関するガイダンス」の中のエン ドポイント特有ガイダンス (Endpoint Specific Guidance) の R.7a，R.7b， R.7c を改訂した新しい付録 を公表した. ${ }^{23)}$ RIP-oN プロジェクトには，ナノテ クノロジー工業協会（Nanotechnology Industries Association; NIA) や欧州化学工業連盟（European Chemicals Industry Council; Cefic）が産業界から加 わっており，報告書完成までに各方面の専門家によ る綿密な調査と分析を積んだ上でその内容について 既に幅広い合意ができていた。また，これらのガイ ダンス付録に続き, ナノマテリアルの登録の際の化 学物質安全性評価に関する手引きとして，5月 25 日には ECHA は，R.8（ヒト健康に関する用量反 応の特性評価)，R.10（環境に関する用量反応の特 性評価）及び R.14（労働曝露の推計）を改訂する 付録を公表した. ${ }^{24)}$

\section{4-2-2. Biocide 関係 殺生物性製品に関する欧} 州指令 98/8/EC は，殺生物性（ナノマテリアルを 含む）物質とその製品の販売に関しその規制が適用 される (ED 98/8/EC)。本指令の目的は, 殺生物 性物質を使用した結果に対し, 労働者を含む人間, 動物及び環境に関する高水準の保護を目的としてい る. 特に第 5.1 条 (b) 項は EU 加盟国に対し, 殺生
物性製品の認可は，当該殺生物性製品が，職場にお ける結果を通じて，直接又は間接であるか問わず, ヒトに許容できない影響を及ぼさないことが立証さ れる場合に限るよう要求している.

EU 内での殺生物剤に関する法制度の調和と認可 手続きの簡素化を目的として，欧州指令 $98 / 8 / E C$ に置き換わる欧州委員会の規則案が 2009 年 6 月に 採択された。 その後, 欧州議会及び欧州理事会の審 議・修正を経て最終的に欧州理事会で採択され， 「殺生物剤の市場での利用可能化と使用に関する 2012 年 5 月 22 日の欧州議会と欧州理事会の規則 (EU) No 528/2012」（いわゆる Biocidal Product Regulation; BPR）として 2012 年 6 月 27 日の官報で公布 された. ${ }^{25)}$ BPR は 2012 年 7 月 17 日から施行され, 2013 年 9 月 1 日から適用される。 BPR におけるナ ノマテリアルの定義は 2011 年 10 月の欧州委員会勧 告の内容が取り入れられており，この定義に照らし てナノマテリアルであると判定される物質が製品に 使用されている場合，そのナノマテリアルがヒト・ 動物の健康及び環境に及ぼすリスクを別途評価する ことが認可の条件として挙げられている.ナノマテ リアルの安全性試験に際しては, その特性に合わせ た調整などを含め，適用した試験法の科学的妥当性 を説明すべきであるとされている，ナノマテリアル に限らず，BPR とこれまでの欧州指令 98/8/EC と の主な変更点としては，(1)適用範囲として殺生物剤 で処理された繊維や家具等の成形品も対象となりラ ベル表示が必要になったこと, (2)EU 全体の認可シ ステムになること（ECHA 及び欧州委員会による 認可の対象は, 新規活性物質含有あるいは低リスク の殺生物剂から始め，それ以外は加盟国による認可 であるが，その後順次， ECHA 及び欧州委員会は 認可の対象を全体にまで拡大，1つの加盟国が認可 した内容は他の加盟国でも認可), (3)デー夕共有化 が義務付けられる，(4)有害性に基づく認可適用外の 活性物質クライテリアは, 発がん性・変異原性・生 殖毒性（CMR）の物質, 難分解性・生体蓄積性 毒性 (PBT) の物質, 非常に難分解性・非常に生体 蓄積性（vPvB）の物質，内分泌かく乱物質とする ことが挙げられている.

4-3. 英国 英国安全衛生庁 (Health and Safety Executive; HSE) がナノマテリアルに関する指針 書を公表しており英国では法律に準ずるものとして 
いる. 2004 年に公表された指針情報（HSE 2004 年) ${ }^{26)}$ では，監視，制御措置，個人用防護具に関す る検討を含む，ナノテクノロジーに伴う安全衛生問 題に関する情報が提供されている．英国における有 害化学物質に対する曝露の制御に適用される法律は 2002 年有害物質管理規則 (Control of Substances Hazardous to Health Regulation; COSHH) である. カーボンナノチューブ (CNT) のリスク管理につ いては，作業活動によってリスクが発生すると考え られる場合は，当該リスクを認知する法的義務を負 うとともに，当該リスクが可能な限り低い水準に抑 えられている状況を維持確認する義務を負うものと 規定としている。 COSHH に基づくリスク評価は CNT を扱うすべての作業を対象に実施するととも に，適切かつ十分なリスク管理措置を講じる必要が あるとしている

\section{4-4. ドイツ ドイツ連邦労働社会省の連邦労} 働安全衛生研究所 (Bundesanstalt für Arbeitsschutz und Arbeitsmedizin; BAuA）とドイツ化学工業協会 (Verband der Chemischen Industrie; VCI) は, 2006 年春, VCI 加盟企業におけるナノマテリアルの取扱 い・使用に関する労働安全衛生を対象とした共同調 査を実施した。この調査の目的は，ナノマテリアル を扱う活動に関し，化学業界に現在適用されている 労働安全衛生措置の概要を把握することにあった. 当該調査結果は，化学業界におけるナノマテリアル の取扱い・使用に関する歓告と作業指示を含む「職 場におけるナノマテリアルの取扱い・使用に関する 指針」の確立に利用されている. ${ }^{27)}$ ドイツ社会災害 保険機関の労働安全衛生研究所は, 職場におけるナ ノ粒子に関するリスク評価を実施し，「職場におけ る超微細エアロゾルとナノ粒子に対する防護措置」 に関する報告書を公表し，「これまで実施された調 査によると，粉塵に対して一般に講じられた防護措 置は超微粒子とナノ粒子に対しても効果的である」

と結論している。 リスク評価と防護措置の仕様との 関連で,ドイツ有害物質規則 (Gefahrstoffverordnung) の第 9 条に規定される措置の優先順位を遵守する必 要がある.さらに労働者対象の教育や職業上の健康 診断の実施など，Gefahrstoffverordnung に基づく 他のすべての責務は，化学物質がナノ粒子形状で存 在するという事実に影響を受けることはないが，通 常通りに遵守すべきであるとしている.
4-5. フランス 公衆衛生審議会（Haut Conseil de la Santé Publique; HCSP) は, カーボンナノ チューブの曝露に直面する労働者の安全に関する 2009 年 1 月 9 日付の見解を発表し，規制措置を導 入するよう勧告している.

フランスは 2012 年 2 月 19 日付官報で政令「環境 規約第 L.523-4 に基づくナノ粒子状の物質の年次申 告に関する 2012 年 2 月 17 日の法令第 2012-232」 を公布した. ${ }^{28)}$ ナノマテリアルに関する EU 初の規 制となり，2013 年 1 月 1 日から施行される。製造 者，輸入者，流通業者は， $100 \mathrm{~g}$ 以上のナノ粒子の 数量，用途などを年次申告する義務があり，ナノ粒 子の定義は, 2011 年 10 月の欧州委員会勧告に沿う ものとなっている。罰則は 2013 年 5 月から適用さ れる。

\section{5. 日本}

日本における，ナノマテリアル関係の具体的な規 制の動きはまだないが 2009 年関係する各省，各局 は専門家委員会を設置し，指針，ガイドライン及び 通達の形式で公表している，厚生労働省医薬食品局 は，「ヒトに対する有害性が明らかでない化学物質 に対する労働者ばく露の予防的対策に関する検討 会」で，平成 21 年 3 月 31 日付ナノマテリアルの安 全対策に関する検討会報告書を公表，さらに同労働 基準局では平成 21 年 3 月 31 日，厚生労働省労働基 準局長名で，改訂版の「ナノマテリアルに対するば く露防止等のための予防的対応について」（基発 331013 号）が通達されている。また経済産業省で は「ナノマテリアル製造事業者等における安全対策 のあり方研究会」報告書が公表されており環境省総 合環境政策局は「ナノ材料環境影響基礎調査検討会」 でのとりまとめを受け，「工業用ナノ材料に関する 環境影響防止ガイドライン」を平成 21 年 3 月 10 日 付で公表している。 2012 年 1 月経済産業省は, 最 新の科学的知見等を踏まえ，使用実態やライフサイ クルを考慮したナノ物質のリスク等を整理し，ナノ 物質の適正な管理のあり方を検討するため，「ナノ 物質の管理に関する検討会」（座長：武林 亨 慶應 義塾大学医学部 教授) を発足させた。本検討会の 下でリスク評価 WG（座長：慶應義塾大学 大前教 授）及び計測技術 WG（座長：同志社大学 森教授） を設置，WGで具体的な検討を進めている。一 方，環境省は 2012 年 1 月からナノ材料の最新の知 
見及び動向をふまえ，環境行政として取り組むべき 今後の課題等について検討を行うため「ナノ材料の 環境影響評価に関する検討委員会」を設置し，検討 に着手した．技術的課題を中心に今後の方向性をと りまとめることとしている．前述したようにわが国 における工業用ナノマテリアルのリスクに関する研 究的取り組みは独立行政法人新エネルギー・産業技 術総合開発機構（NEDO）の委託事業として，独 立行政法人産業技術総合研究所を核とする共同プロ ジェクトが精力的に進められている，独立行政法人 物質・材料研究機構, 環境省, 厚生労働省などが積 極的に研究に取り組んでいる。このなかで，ナノマ テリアルのキャラクタリゼーションから始まり，リ スクアセスメントまでを総括して進める NEDO プ ロジェクトは，OECD プロジェクトとして国際的 に認知されたものと位置づけられている，産業界の 取り組みとして前述のナノテクノロジービジネス推 進協議会 (NBCI) はナノテク材料のメーカー, ユー ザー等に対し，ナノテクのベネフィットとリスクに 係わる情報を発信しており，安全面での取り組み は，社会受容・標準化委員会で検討している。最近 は従来の標準化作業（ISO TC 229）主体の取り組 みに加え OECD-WPMN への対応にも活動を拡大 し協力している. 日本化学工業協会は前述したよう に，OECD，政府機関及び関連諸団体と多様な取り 組みを行っている，各種機関，取り組みの概要を示 す (Fig. 2).

\section{6. まとめ}

以上，国際的な取り組みとともに現状のナノマテ リアルに関する各国，各局の規制及び指針，通達及

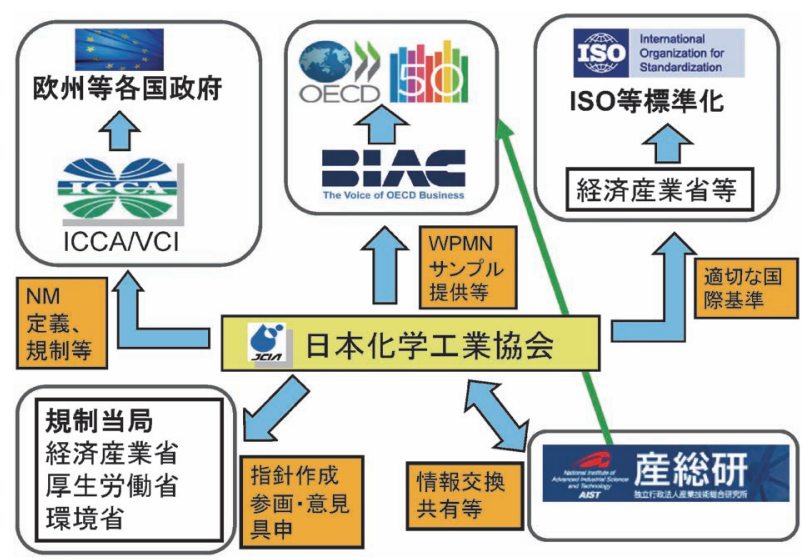

Fig. 2. JCIA's Various Activities
びガイドライン等について概説した。米国 TSCA の例でもみられるように具体的に特定の物質につい て規制が開始されているところもあり，今後世界的 に規制の内容が具体化かつ拡大していくものと思わ れる，米国と EU における規制枠組みは，職業別の 全般的な化学物質安全性に関する立法に依拠してい るという点で類似した特徵を有している。米国と EUはいずれも，一般的なリスク評価・管理，とり わけ職場におけるナノマテリアルに関し，欧州規則 は現在，化学物質に適用される既存の法律と規則に 基づく形となっている．日本においてもそれぞれの 環境，作業者及び消費者等の各管理対象に従って必 要な指導やガイドラインが各対応官庁から公表され ている. 今後の課題として, ナノマテリアルは画一 的な作業者保護の観点での管理と作業者保護対策が 難しい点がある，すなわち，ナノマテリアルといっ ても多種多様であり，「ナノマテリアル」といった 一元的定義の下での管理は妥当ではない．またその リスクも同じ化学物質であってもその形状, サイズ 等が異なれば体内動態も異なり全く異なるエンドポ イントを示すことも考えられる．ナノマテリアルの 定義については既に議論が開始され，今後具体的な 管理について規制が策定されていくと思われるが, 今後国際的な流れの中でその研究成果・調查結果を 十分考慮したうえでリスクベースでの慎重かつ適切 な環境対策，消費者及び作業者保護対策が必要だと 思われる。

\section{REFERENCES}

1) U.S. Department of Energy Nanoscale Science Research Centers. "Approach to Nanomaterial ES\&H, Revision-3a May 2008.”: 〈http:// science.energy.gov/ / media/bes/pdf/doe nsrc_approach_to_nanomaterial_esh.pdf $\rangle$, cited 12 May, 2008.

2) U.S. Department of Energy. "Notice: The Safe Handling of Unbound Engineered Nanoparticles. DOE N 456.1.": 〈http://www. directives.doe.gov/pdfs/doe/doetext/neword /456/n4561.pdf $\rangle$, cited 17 December, 2009.

3) U.S. Environmental Protection Agency, Fed. Regist., 73(215), 65743-65766 (2008).

4) U.S. Environmental Protection Agency. "TSCA Inventory Status of Nanoscale Substances -General Approach, January 23, 2008.': 
〈http: // www.epa.gov / oppt / nano / nmsp-inventorypaper2008.pdf $\rangle$, cited 23 January, 2008.

5) U.S. Environmental Protection Agency, Fed. Regist., 73 (212) , 64946-64947 (2008).

6) U.S. Environmental Protection Agency. "Control of Nanoscale Materials under the Toxic Substances Control Act.'’: 〈http:// www.epa.gov/oppt/nano〉, cited 29 April, 2011.

7) U.S. Environmental Protection Agency. “Enhancing EPA's Chemical Management Program.": 〈http://www.epa.gov/oppt/existingchemicals/pubs/enhanchems.html $>$, cited 19 July, 2012.

8) U.S. Environmental Protection Agency, Fed. Regist., 74(214), 57430-57436 (2009).

9) U.S. Environmental Protection Agency, Fed. Regist., 75 (180), 56880-56889 (2010).

10) U.S. Environmental Protection Agency, Fed. Regist., 77 (65), 20296-20308 (2012).

11) U.S. Environmental Protection Agency, Fed. Regist., 72 (183), 54039-54041 (2007).

12) U.S. Environmental Protection Agency, Fed. Regist., 74(178), 47575-47578 (2009).

13) U.S. Environmental Protection Agency, Fed. Regist., 76(117), 35383-35395 (2011).

14) U.S. Food and Drag Administration. "FDA News Release, FDA Issues Draft Guidance on Nanotechnology.": 〈http: // www.fda.gov / NewsEvents/Newsroom/PressAnnouncements /ucm301125.htm〉, cited 20 April, 2012.

15) European Commission. "Community Research, Nanosciences and Nanotechnologies: An Action Plan for Europe 2005-2009.": 〈http:// ec.europa.eu/research/industrial_technologies /pdf/nano_action_plan_en.pdf $\rangle$, cited 22 November, 2012.

16) European Commission. "Communication from the Commission to the European Parliament, the Council and the European Economic and Social Committee, Regulatory Aspects of Nanomaterials, COM(2008) 366, SEC (2008) 2036."': 〈http:// eur-lex.europa.eu/ LexUriServ/LexUriServ.do? uri = COM:2008: 0366:FIN:en:PDF $\rangle$, cited 22 November, 2012.

17) European Commission. "Scientific Committee on Emerging and Newly Identified Health Risks, Scientific Basis for the Definition of the
Term "Nanomaterial",.": 〈http://ec.europa. eu / health / scientific_committees / emerging / docs/scenihr_o_032.pdf $\rangle$, cited 22 November, 2012.

18) European Commission, Official Journal of the European Union, L 275, 20.10.2011, 38-40 (2011).

19) European Parliament. "Texts Adopted at the sitting of Friday 20 April 2012."': 〈http:// www.europarl.europa.eu / RegData / seance pleniere/textes_adoptes/provisoire/2012/0420/P7_TA-PROV (2012) 04-20_EN.pdf $\rangle$, cited 20 April, 2012.

20) European Parliament and the Council of the European Union, Official Journal of the European Union, L 396, 30.12.2006, 1-849 (2006).

21) European Commission DG Environment. “'Nanomaterials, Nano Support Project.": $\langle$ http://ec.europa.eu/environment/chemicals /nanotech/\#support〉, cited 22 November, 2012.

22) European Commission. "Nano Support Project, Scientific Technical Support on Assessment of Nanomaterials in REACH Registration Dossiers and Adequacy of Available Information.": 〈http://ec.europa.eu/environment / chemicals / nanotech / pdf / jrc_report. pdf $\rangle$, cited 12 March, 2012.

23) European Chemicals Agency. "Guidance on Information Requirements and Chemical Safety Assessment."':〈http://echa.europa.eu /web/guest/guidance-documents/guidance-oninformation-requirements-and-chemical-safetyassessment $\rangle$, cited 30 April, 2012.

24) European Chemicals Agency. "Further Updated Guidance on Information Requirements and Chemical Safety Assessment for Nanomaterials.'”: 〈http://echa.europa.eu/web/guest/ view-article / - / journal _ content / df1811938b2c-433a-8c80-f7fcf7546077>, cited 25 May, 2012.

25) European Parliament and the Council of the European Union, Official Journal of the European Union, L 167, 27.06.2012, 1-123 (2012).

26) U.K. Health and Safety Executive. "Nanotechnology, Horizons Scanning Information Note No HSIN1.'”:〈http://www.nano.org.uk / members / FreeReports / Nanofactsheet.pdf $>$, cited 22 November, 2012. 
27) Bundesanstalt für Arbeitsschutz und Arbeitsmedizin (BAuA), Verband der Chemischen Industrie (VCI), "Guidance for Hanlding and Use of Nanomaterials at the Workplace.": 〈http://www.baua.de/nn_49456/en/Topicsfrom-A-to-Z / Hazardous-Substances / Nanotechnology/pdf/guidance.pdf $\rangle$, cited 12 September, 2007.

28) French Government, "Décret n 2012-232 du
17 février 2012 relatif à la déclaration annuelle des substances à l'état nanoparticulaire pris en application de l'article L. 523-4 du code de l'environnement.": 〈 http: // www.legifrance.gouv.fr / affichTexte.do;jsessionid = ?cidTexte $=$ JORFTEXT000025377246\&dateTexte $=$ \&oldAction $=$ rechJO\&categorieLien $=\mathrm{id}\rangle$, cited 19 February, 2012. 